\title{
Beta-2 Microglobulin Measurement
}

National Cancer Institute

\section{Source}

National Cancer Institute. Beta-2 Microglobulin Measurement. NCI Thesaurus. Code C81980.

The determination of the amount of beta-2 microglobulin present in a sample. 